\title{
Synthesis of C-8 alkyl xanthines by pentaamminecobalt(III) complex
}

\author{
Renuka Suravajhala \\ Department of Science, Systems and Models, Roskilde University, Roskilde, Denmark \\ Email: renu@,ruc.dk
}

Received 8 September 2013; revised 15 October 2013; accepted 29 October 2013

Copyright (C) 2013 Renuka Suravajhala. This is an open access article distributed under the Creative Commons Attribution License, which permits unrestricted use, distribution, and reproduction in any medium, provided the original work is properly cited.

\begin{abstract}
Alkyl xanthines underwent selective homolytic aromatic substitution at C-8 position with alkyl groups of pentaamminecobalt(III) complex. In this process of synthesis, we used monoalkyl hydrazines as the radical source in aqueous ammonia solution. Evidence supporting coordination of the alkyl hydrazine to pentaamminecobalt(III) complex by radical trapping was in good agreement with literature. The products were characterized using GC-MS and ${ }^{1} \mathrm{H},{ }^{14} \mathrm{~N}$ and ${ }^{59}$ Co NMR spectroscopy.
\end{abstract}

Keywords: Alkyl Hydrazine; Radical Alkylation; Caffeine; Homolytic Aromatic Substitution; Pentaamminecobalt(III)

\section{INTRODUCTION}

Alkyl xanthines belong to purine group of molecules and are of interest due to their therapeutic value. A number of xanthines are used as adenosine receptor antagonists to treat neurodegenerative diseases in humans [1]. Several xanthines are known to inhibit cells at the G2 checkpoint in the cell cycle, thereby making cells more sensitive to DNA damage [2]. Xanthines, such as caffeine, theophylline, theobromine (see Figure 1) and its derivatives have been used for antihyperuraemic therapy, inhibition of monoamine oxidase B [3], besides serving as anticancer agents. Xanthines are known to enhance affinity for certain receptors selectively as well. This has led to an interest in synthesizing substituted alkyl xanthines.

Aqueous organometallic chemistry and its catalysis have attracted much interest, partly due to the reduced requirement for organic solvents [4]. Many organocobalt(III) complexes are sensitive to oxygen or moisture. Hydrolysis of a cobalt(III)-carbon bond is dependent on the nature of the ligand and requires mild conditions. Alkylcobalt(III) complex acts as a potential radical sour- ce, e.g. in organic synthesis [5] such as oxidation, reduction, thermolysis, photolysis and sonolysis. Homolytic aromatic substitution is a well-known method for the preparation of 8-substituted xanthines. Previously, 8-methylcaffeine was known to be prepared by irradiation of a mixture of caffeine and tert-butyl peracetate with ultraviolet light [6]. Similarly, 8-(1-adamantyl) caffeine and 8-cyclohexyl caffeine were obtained by employing photochemically prepared radicals [7] while other 8-alkyl xanthines were known to be synthesized by reaction with solvent-derived alkyl radicals using benzoyl peroxide as a radical initiator [8].

Till date, no studies have been focused on Cobalt catalysed synthesis of C-8 alkyl xanthines. In this study, an attempt was made to synthesize and purify C-8 substituted alkyl xanthines.

\section{MATERIAL AND METHODS}

Concentrated aqueous $\mathrm{NH}_{3}(5 \mathrm{~mL})$ was added to a solution of $\mathrm{Co}\left(\mathrm{NO}_{3}\right)_{2} \cdot 6 \mathrm{H}_{2} \mathrm{O}(30 \mathrm{mg}, 0.1 \mathrm{mmol})$, the monoalkyl hydrazine $(2.0 \mathrm{mmol})$, and methyl xanthine (1.0 $\mathrm{mmol})$ in $\mathrm{H}_{2} \mathrm{O}(10 \mathrm{~mL})$. The mixture was stirred for 8 $10 \mathrm{~h}$ at room temperature in presence of atmospheric dioxygen. The reaction was monitored by GC-MS after extraction into $\mathrm{CH}_{2} \mathrm{Cl}_{2}$. Following completion, the product was extracted into $\mathrm{CH}_{2} \mathrm{Cl}_{2}(25 \mathrm{~mL})$ and the solvent was removed by rotary evaporation. The resulting solid was dissolved in a 2:3 mixture of ethoxyacetate, $n$-hexane $(5 \mathrm{~mL})$ and purified by column chromatography using silica gel (mesh, 11, $3.5 \mathrm{~cm}$ ) and a 2:3 mixture of ethoxyacetate and $n$-hexane as eluent. The pure compounds were isolated and further characterized by GCMS, ${ }^{1} \mathrm{H}$ NMR and elemental analysis (See Figure 2).

\section{RESULTS AND DISCUSSION}

The 8-alkyl xanthines have been synthesized and characterized using GC-MS and ${ }^{1} \mathrm{H}$ NMR. Further elemental analysis of the isolated compounds was done which were 
<smiles>Cn1cnc2[nH]c(=O)[nH]c(=O)c21</smiles><smiles>Cn1c(=O)c2[nH]cnc2n(C)c1=O</smiles><smiles>Cn1cnc2c1c(=O)[nH]c(=O)n2C</smiles><smiles>Cn1c(=O)c2c(ncn2C)n(C)c1=O</smiles>

Figure 1. Structures of xanthine and its derivatives.

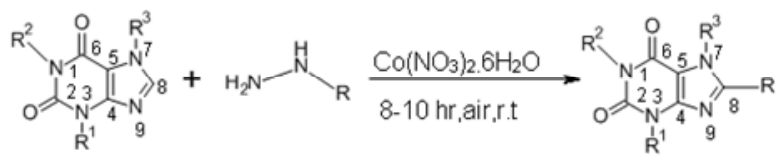

Figure 2. Preparation of C-8 substituted alkyl xanthines.

in agreement with respect to molecular structures. While the following seven compounds synthesized, viz. 8-tertbutyl caffeine, 8-tertbutyl theophylline, 8-tertbutyl-3isobutyl-1-methyl-theophylline,8-isopropyl -3- isobutyl1-methyl theophylline, 8-isopropyl caffeine,8-isopropyl theophylline and 8-isopropyl theobromine; had a conversion of $60 \%-90 \%$ (See Table 1). These were further used to study their effect in cancer cell lines. However, two compounds, viz. 8-ethyl caffeine and 8-ethy tertbutyl theobromine were not considered due to their insolubility in aqeous solution. Although we tried to synthesize many compounds, we wereable to get good yields for secondary and tertiary alkly hydrazines which have predominantly yielded 8 -substituted alkly xanthines

The reaction of monoalkyl hydrazines with cobalt (III) in aqueous ammonia in the presence of atmospheric oxygen was analysed by ${ }^{14} \mathrm{~N}$ and ${ }^{59} \mathrm{Co}$ NMR. A solution of $0.1 \mathrm{M} \mathrm{Co}\left(\mathrm{NO}_{3}\right)_{2}$ in $4 \mathrm{M} \mathrm{NH}_{3}$ provided a ${ }^{59} \mathrm{Co} \mathrm{NMR}$ signal at $8759 \mathrm{ppm}$ (line width at half height, $\Delta v^{1 / 2}=11.2$ $\mathrm{kHz}$ ), which was assigned to the diamagnetic

$\left[\left(\mathrm{NH}_{3}\right)_{5} \mathrm{CoOOCo}\left(\mathrm{NH}_{3}\right)_{5}\right]^{4+}$ and is in agreement with the literature [11]. Addition of a stoichiometric amount of a methyl hydrazine (or another alkyl hydrazine) to the solution resulted in immediate disappearance of the ${ }^{59} \mathrm{Co}$ NMR signal. Rapid gas evolution (presumably $\mathrm{O}_{2}$ ) together with the disappearance of $\left[\left(\mathrm{NH}_{3}\right)_{5} \mathrm{CoOOCo}\left(\mathrm{NH}_{3}\right)_{5}\right]^{4+}$ was consistent with methyl hydrazine displacing the co- ordinated dioxygen to give a cobalt(III) compound. This was oxidized slowly to the $\left[\mathrm{Co}\left(\mathrm{NH}_{3}\right)_{5}\left(\mathrm{CH}_{3}\right)\right]^{2+}$ cation which was evident by the appearance of a ${ }^{59} \mathrm{Co}$ signal at $7370 \mathrm{ppm}\left(\Delta v^{1 / 2}=13.2 \mathrm{kHz}\right)$ (Figure 3) [9].

Magnetic susceptibility measurements in solution following Evans method [10] using tert-butanol with ${ }^{1} \mathrm{H}$ NMR detection showed that a solution of $0.1 \mathrm{M}$ $\mathrm{Co}\left(\mathrm{NO}_{3}\right)_{2}$ in $4 \mathrm{M} \mathrm{NH}_{3}$ was essentially diamagnetic and consistent with formation of the $\left[\left(\mathrm{NH}_{3}\right)_{5} \mathrm{CoOOCo}\left(\mathrm{NH}_{3}\right)_{5}\right]^{4+}$ cation. Addition of a stoichiometric amount of methyl hydrazine resulted in a paramagnetic species. This was consistent with the disappearance of the ${ }^{59} \mathrm{Co}$ NMR signal. Coordination of dioxygen to yield diamagnetic cobalt(III) complexes, as indicated by the ${ }^{59} \mathrm{Co}$ NMR signals, was conceivable indicating that dioxygen oxidizes the alkyl hydrazine via simultaneous coordination to the cobalt ion. Although many cobalt-dioxygen complexes are known to form in aqueous solution [11], to our knowledge, there are no reports on cobalt coordination compounds with both alkyl hydrazines and dioxygen ligands. Nevertheless, in view of many studies on cobalt-dioxygen complex formation with nitrogen donor ligands [12], it appears plausible that such species may form as intermediates. The ${ }^{1} \mathrm{H}$ NMR spectra of the reaction mixtures showed that oxidation, e.g. of ethyl hydrazine gives a $\left[\mathrm{Co}\left(\mathrm{NH}_{3}\right)_{5}\left(\mathrm{CH}_{2} \mathrm{CH}_{3}\right)\right]^{2+}$ cation prior to xanthine alkylation. The ethyl ${ }^{1} \mathrm{H}$ NMR resonance signals of the ethyl hydrazine gradually decreased and instead, two new resonances at 3.90 and $3.97 \mathrm{ppm}$ appeared. These were assigned to the $\left[\mathrm{Co}\left(\mathrm{NH}_{3}\right)_{5}\left(\mathrm{CH}_{2} \mathrm{CH}_{3}\right)\right]{ }^{2+}$ cation by comparison with data for the isolated coordination compound [12].

The latter compound disappeared slowly and the formation of 8-ethylcaffeine was observed by the presence of appropriate ${ }^{13} \mathrm{C}$ and ${ }^{1} \mathrm{H}$ resonance signals along with ${ }^{14} \mathrm{~N}$ NMR studies. A solution of methyl hydrazine in $6 \mathrm{M}$ $\mathrm{NH}_{3}$ yielded a broad ${ }^{14} \mathrm{~N}$ signal (-299 ppm); addition of a $25 \mathrm{M}$ solution of $\mathrm{Co}\left(\mathrm{NO}_{3}\right)_{2}$ yielded signals correlating with $-\mathrm{NH}-\mathrm{NH}_{2}(-262 \mathrm{ppm},-331 \mathrm{ppm})$. Thus we observe that the oxidation of hydrazine with cobalt(III) takes place prior to alkylation of the alkylated xanthine.

This interpretation implies coordination of the alkyl hydrazine to cobalt(III) and is supported by the fact that methyl and ethyl hydrazine have been demonstrated to act as unidentate or bidentate bridging ligands towards cobalt(III) $[13,14]$. The rapid exchange reactions studied in alkylcobalt(III) complexes allow detection of alkyl radical released during the decomposition in aqueous solution. For example, in the case of pentaammine methylcobalt(III) complex $\left[\mathrm{Co}\left(\mathrm{NH}_{3}\right)_{2}\left(\mathrm{CH}_{3}\right)\left(\mathrm{NO}_{3}\right)_{2}\right]$ the methyl radical can be trapped by $\alpha$-phenyl- $N$-tert-butylnitrone $(\mathrm{PBN})$ with the appearance of a $\left({ }^{14} \mathrm{~N}\right): 16.89 \mathrm{G}$ signal, and furthermore, on addition of caffeine, there were no signals observed due to a methyl adduct of PBN. 
Table 1. The \% conversion of C-8 substituted alkyl xanthines.

\begin{tabular}{cccccccc}
\hline Product & $\mathrm{R}^{1}$ & $\mathrm{R}^{2}$ & $\mathrm{R}^{3}$ & $\mathrm{R}$ & $\begin{array}{c}\text { Conversion } \\
\text { 8-ethylcaffeine }\end{array}$ & $\begin{array}{c}\text { Expected yeild } \\
\text { mmol }\end{array}$ & $\begin{array}{c}\text { Isolated Yeild } \\
\mathrm{g} / \mathrm{mmol}\end{array}$ \\
\hline 8-tert-butyl-3-isobutyl-1-methyl xanthine & $\mathrm{CH}_{3}$ & $\mathrm{CH}_{3}$ & $\mathrm{CH}_{3}$ & $\mathrm{Et}$ & $20 \%$ & 0.16 & $10 \mathrm{mg} / 0.045 \mathrm{mmol}$ \\
8-tert-butylcaffeine & $\mathrm{CH}_{3}$ & $\mathrm{CH}_{3}$ & $\mathrm{CH}_{3}$ & $\mathrm{tBu}$ & $55 \%$ & 0.35 & $110 \mathrm{mg} / 0.39 \mathrm{mmol}$ \\
8-tert-butyl theophylline & $\mathrm{CH}_{3}$ & $\mathrm{CH}_{3}$ & $\mathrm{H}$ & $\mathrm{tBu}$ & $95 \%$ & 0.49 & $102 \mathrm{mg} / 0.43 \mathrm{mmol}$ \\
8-tert-butyl theobromine & $\mathrm{H}$ & $\mathrm{CH}_{3}$ & $\mathrm{CH}_{3}$ & $\mathrm{tBu}$ & $15 \%$ & 0.1 & $16 \mathrm{mg} / 0.17 \mathrm{mmol}$ \\
8-isopropyl -3-isobutyl-1-methyl xanthine & $\mathrm{CH}_{3}$ & $\mathrm{iBu}$ & $\mathrm{H}$ & $\mathrm{iPr}$ & $70 \%$ & 0.7 & $20 \mathrm{mg} / 0.75 \mathrm{mmol}$ \\
8-isopropyl caffeine & $\mathrm{CH}_{3}$ & $\mathrm{CH}_{3}$ & $\mathrm{CH}_{3}$ & $\mathrm{iPr}$ & $58 \%$ & 0.6 & $40 \mathrm{mg} / 0.16 \mathrm{mmol}$ \\
8-isopropyl theophylline & $\mathrm{CH}_{3}$ & $\mathrm{CH}_{3}$ & $\mathrm{H}$ & $\mathrm{iPr}$ & $67 \%$ & 0.67 & $35 \mathrm{mg} / 0.15 \mathrm{mmol}$ \\
8-isopropyl theobromine & $\mathrm{H}$ & $\mathrm{CH}_{3}$ & $\mathrm{CH}_{3}$ & $\mathrm{iPr}$ & $90 \%$ & 0.9 & $30 \mathrm{mg} / 0.15 \mathrm{mmol}$ \\
\hline
\end{tabular}

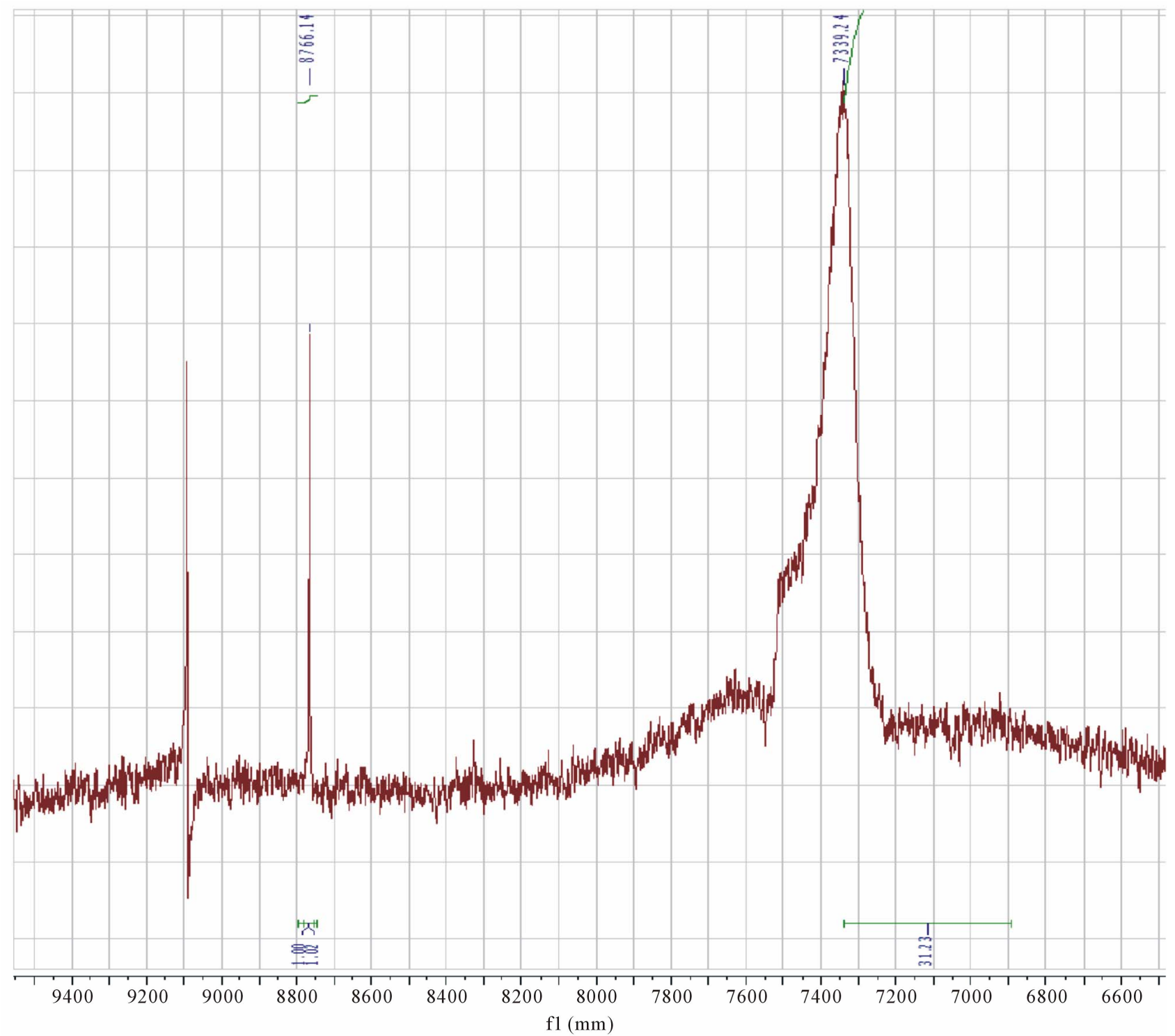

Figure 3. ${ }^{59} \mathrm{Co} \mathrm{NMR}$ signal at $\delta=8759 \mathrm{ppm}\left[\left(\mathrm{NH}_{3}\right)_{5} \mathrm{CoOOCo}\left(\mathrm{NH}_{3}\right)_{5}\right]^{4+}$ cation, and $\delta=7370 \mathrm{ppm}\left[\mathrm{Co}\left(\mathrm{NH}_{3}\right)_{5}\left(\mathrm{CH}_{3}\right)\right]^{2+}$ cation in DMSO-d6. 


\section{CONCLUSION}

We report that cobalt(III) in aqueous ammonia solution serves as a catalyst for obtaining new carbon-carbon bonds by homolytic aromatic substitution. The amminecobalt(III)-promoted aerial oxidation of alkyl hydrazines afforded alkyl radicals, and some primary alkyl radicals were trapped by pentaamminecobalt(III) to form alkyl cobalt(III) cations [15]. However, these compounds are labile and decomposed to return alkyl radicals. It has been previously shown that the $\left[\mathrm{Co}\left(\mathrm{NH}_{3}\right)_{5}\left(\mathrm{CH}_{3}\right)\right]^{2+}$ cation acts as a methylating agent toward the C-8 atom of purine nucleotides [16-18]. We have applied a number of alkyl radicals for the preparation of C-8 substituted alkyl xanthines. We were unable to obtain evidence of a cobalt(III) species with both an alkyl hydrazine ligand and a peroxo ligand. However, this does not exclude the possibility of such a species existing as a reactive intermediate. It may be speculated that a cobalt(III) species with both an alkyl hydrazine ligand and a peroxo ligand is very shortlived due to rapid oxidation of alkylhydrazine.

\section{ACKNOWLEDGEMENTS}

Grateful appreciations towards financial support for the work carried out were rendered to the Danish Natural Science Research Council. The author thanks Drs. Pauli Kofod and AS Kumbhar for reviewing the manuscript.

\section{REFERENCES}

[1] S.M. Kaiser and R. J. Quinn, "Adenosine Receptors as Potential Therapeutic Targets," Drug Discovery Today, Vol. 4, No. 12, 1999, pp. 542-551. http://dx.doi.org/10.1016/S1359-6446(99)01421-X

[2] A. Tenzer and M. Pruschy, "Potentiation of DNA-DamageInduced Cytotoxicity by G2Checkpoint Abrogators," Current Medicinal Chemistry-Anti-Cancer Agents, Vol. 3, No. 1, 2003, pp. 35-46. http://dx.doi.org/10.2174/1568011033353533

[3] F. Borges, E. Fernandes and F. Roleira, "Progress towards the Discovery of Xanthine Oxidase Inhibitors," Current Medicinal Chemistry, Vol. 9, No. 2, 2002, pp. 195-217. http://dx.doi.org/10.2174/0929867023371229

[4] F. Joo, "Aqueous Organometallic Catalysis," Springer Series, Vol. 23, 2001, pp. 312-318.

[5] S. Z. Zard, "Radical Reactions in Organic Synthesis," Oxford University Press, Oxford, 2003.

[6] M. F. Zady and J. L. Wong, " Reactivities and Electronic Aspects of Nucleic Acid Heterocycles. Part 6. Kinetics and Mechanism of Carbon-8 Methylation of Purine Bases and Nucleosides by Methyl Radical," Journal of the American Chemical Society, Vol. 99, No. 15, 1977, pp.
5096-5101. http://dx.doi.org/10.1021/ja00457a033

[7] E. Castagnino, S. Corsano, D. H. R. Barton and S. Z. Zard, "Decarboxylative Radical Addition onto Protonated Heteroaromatic Systems Including Purine Bases," Tetrahedron Letters, Vol. 27, No. 52, 1986, pp. 6337-6338. http://dx.doi.org/10.1016/S0040-4039(00)87802-8

[8] T. Itahara and N. Ide, "Free Radical Alkylation of 1,3Dimethyluracils and Caffeine with Benzoyl Peroxide," Bulletin of the Chemical Society of Japan, Vol. 65, No. 8, 1992, pp. 2045-2049. http://dx.doi.org/10.1246/bcsj.65.2045

[9] P. Kofod, "The Pentaamminemethylcobalt(III) Cation: Synthesis and Spectroscopic Characterization," Inorganic Chemistry, Vol. 34, No. 10, 1995, pp. 2768-2770. http://dx.doi.org/10.1021/ic00114a040

[10] J. Evans, "Biomolecular NMR Methods," Oxford University Press, Oxford, 1995.

[11] R. D. Jones, D. A. Summerville and F. Basolo, "Synthetic Oxygen Carriers Related to Biological Systems," Chemical Reviews, Vol. 79, No. 2, 1979, pp. 139-179. http://dx.doi.org/10.1021/cr60318a002

[12] D. Nicholls, M. Rowley and R. Swindells, "Hydrazine Complexes of Cobalt(II) Chloride," Journal of the Chemical Society, Vol. 5, 1996, pp. 950-953.

[13] A. Anagnostopoulos and D. J. Nicholls, "Some Complexes of Hydrazine, Methylhydrazine and 1,1-Dimethylhydrazine with Cobalt(II) Salts," Journal of Inorganic and Nuclear Chemistry, Vol. 38, No. 9, 1976, pp. 1615-1618. http://dx.doi.org/10.1016/0022-1902(76)80646-X

[14] A. A. Rahman, M. P. Brown, M. M. Harding, C. E. Keggan and D. Nichols, "Coordination Compounds of Ethylhydrazine and 2,2,2-Trifluoroethylhydrazine; Crystal and Molecular Structure of Dichlorotetrakis(2,2,2Trifluoroethylhydrazine) Nickel(II)," Polyhedron, Vol. 7, No. 13, 1988, pp. 1147-1152. http://dx.doi.org/10.1016/S0277-5387(00)81202-4

[15] P. Kofod, "Alkylcobalt(III) Compounds with Ammine Ligands," Inorganic Chemistry Communications, Vol. 8, No. 10, 2005, pp. 943-946. http://dx.doi.org/10.1016/j.inoche.2005.07.014

[16] P. Kofod, "GMP and AMP as Methyl Radical Traps in the Reaction with Pentaamminemethylcobalt(III)," Journal of Inorganic Biochemistry, Vol. 98, No. 11, 2004, pp. 1978-1980. http://dx.doi.org/10.1016/j.jinorgbio.2004.08.014

[17] S. C. F. Au-Yeung, S. Eaton and R. Donald, "A Model for Estimating 59Co nmr Chemical Shifts and Line Widths and Its Application to Cobalt Dioxygen Complexes," Canadian Journal of Chemistry, Vol. 61, No. 10, 1983, pp. 2431-2441. http://dx.doi.org/10.1139/v83-420

[18] R. Suravajhala, N. Suri, M. Bhagat and A. K. Saxena, "Biological Evaluation of 8-Alkyl Xanthines as Potential Cytotoxic Agents," Advances in Biological Chemistry, Vol. 3, No. 3, 2013, 314 